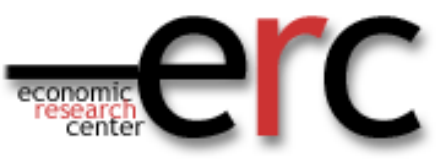

ERC Working Papers in Economics 08/01

April 2008

\title{
Impact of the 1999 Earthquakes on the Outcome of the 2002 Parliamentary Election In Turkey
}

\author{
Ali T. Akarca \\ Department of Economics (mc 144) \\ University of Illinois at Chicago \\ 601 S. Morgan Street \\ Chicago, Illinois 60607, USA \\ Email: akarca@uic.edu \\ Aysit Tansel \\ Department of Economics \\ Middle East Technical University \\ Ankara 06531 Turkey \\ Email: atansel@metu.edu.tr
}




\title{
IMPACT OF THE 1999 EARTHQUAKES ON THE OUTCOME OF THE 2002 PARLIAMENTARY ELECTION IN TURKEY (*)
}

By

\author{
Ali T. Akarca (**) \\ Department of Economics (mc 144) \\ University of Illinois at Chicago \\ 601 S. Morgan Street \\ Chicago, Illinois 60607, USA \\ E-mail: akarca@uic.edu \\ Telephone: 1312 996-1416 \\ and \\ Aysit Tansel \\ Department of Economics \\ Middle East Technical University, \\ 06531 Ankara, Turkey \\ and \\ Institute for the Study of Labor (IZA) \\ P.O. Box 7240, D-53072 \\ Bonn, Germany \\ E-mail: atansel@metu.edu.tr \\ Telephone: 90312 210-2057
}

(*) This work has benefited from a financial grant from the Economic Research Forum within the framework of the Regional Research Competition funded by the Global Development Network. The contents and recommendations do not necessarily reflect the views of the Economic Research Forum. We would like to thank Cengizhan Güder, Mehmet Dikmen and Bülent Özmen for guiding us to the data sources, and to Aydın Bozdemir and Ulvi Askerov for assisting us in gathering and organizing the data. An earlier version of this paper was presented at the $14^{\text {th }}$ Annual Conference of the Economic Research Forum held in Cairo, Egypt, in December 2007. We have benefited greatly from the comments we have received from our audience there. The detailed comments and suggestions provided to us by Mustapha Nabli, our discussant, was especially valuable.

(**) Author of contact 


\begin{abstract}
The two major earthquakes which struck northwestern Turkey in 1999, not only caused enormous amounts of death, destruction and suffering, but also exposed rampant government corruption involving construction and zoning code violations. The incompetence shown by the government in providing relief, the corruption allegations in regards to those efforts, and government's failure to prosecute corrupt officials and businessmen, further angered the public. How voters responded to these in the 2002 parliamentary election is investigated, using cross-provincial data, and controlling for other social, political and economic factors. Our results show that voters held accountable all of the political parties which participated in governments during the last decade or so, and not just the incumbents in 2002. The party in charge of the ministry responsible for earthquake relief, and parties that served longest and controlled more of the city administrations in the quake zone were blamed more. The newly formed Justice and Development Party (AKP) was the beneficiary of the votes lost by these parties. The sensitivity shown by the electorate to real and perceived corruption implies that corruption problem will be tractable in Turkey, and can be reduced through increased transparency and democratization.
\end{abstract}

Keywords: Turkey; Earthquake; Corruption; Election; Party preference; Turkey

JEL Classifications: D72, D73, Q54 


\section{INTRODUCTION}

On 17 August 1999 and 12 November 1999, two major earthquakes, measuring 7.4 and 7.2 on the Richter scale, struck densely populated and heavily industrialized northwestern section of Turkey. These not only caused tens of thousands of deaths and billions of dollars of destruction, but also exposed rampant government corruption involving violation of construction and zoning codes. While a lot of the old buildings remained standing after the quakes, many of the recently constructed ones folded in on themselves due to their unsafe locations and inappropriate design, substandard practices employed in their construction, such as use of concrete prepared with sea sand and insufficient amount of cement and steel bars. What angered the public even more were the government's poor performance in coming to the help of the earthquake survivors, and its failure to prosecute, except for a few scapegoats, the corrupt contractors and government inspectors. News reports on corruption involved in granting contracts for construction of new housing for the quake survivors and other relief related activities further intensified the public outrage.

Green (2005) explains, in detail, how corruption magnified the above disasters in Turkey. Escalares, et al. (2007), who studied 344 major quakes in 42 countries during 1975-2003, found that public sector corruption is positively related to earthquake fatalities in other countries as well.

Our purpose in this paper is to study the response of voters in the 2002 general election, the first one following the 1999 earthquakes, to the above events. First, we would like assess whether the Turkish voters have exhibited any sensitivity to government corruption and incompetence. If they have, we would like gauge how appropriately they have allocated the responsibility for these, among various political parties. In particular, we would like to determine whether the voters held previous governments which were in power when the shoddy buildings were constructed, responsible as well, and whether they distinguished between the parties which controlled municipal administrations in the earthquake zone and those that did not. In Turkey, municipalities issue the permits for constructions and inspect them but they are overseen by the central government. The latter by granting frequent amnesties for improperly and illegally constructed buildings, and the former by providing utilities and other services to them, encourage their spread.

Answers to the above questions will yield useful insights as to how tractable the issue of corruption is in Turkey, and what approaches are likely to be effective in fighting it. Mishra (2005) shows that when corruption is pervasive, it is also likely to be persistent. He points out that when public condones corruption, expected cost of being corrupt (including probability of apprehension and social sanction associated) would be less, leading to more people being corrupt. Then corrupt behavior becomes the equilibrium or the norm. This in turn, would hamper economic progress of the country. Meon and Sekkat (2005), Pellegrini and Gerlagh (2004), Mo (2001), and Mauro (1995) find corruption to lower investment. Countries with high levels of public sector corruption are found to receive less foreign aid, by Alesina and Weder (2002), and less 
foreign direct investment, by Habib and Zurawicki (2002). Tanzi and Davoodi (1997) and Mauro (1997) find that corruption shifts public expenditures from growth-promoting to low-productivity projects. Murphy, et al. (1991, 1993) show that public corruption would drive potential entrepreneurs to rent-seeking activities, or even to becoming corrupt officials themselves, instead of organizing and improving worthwhile production activities. Therefore, we can say that corruption leads to diminished and misallocated resources and thus to low growth.

A secondary aim of our study is to shed some more light on the outcome of the 2002 parliamentary election in Turkey. In that election, the aggregate vote share of the three incumbent parties dropped to 14.7 percent, from 53.4 percent in 1999. Akarca and Tansel (2006) show that the outcome of the 2002 election was an outlier, compared to 24 other elections held in Turkey between 1950 and 2004. They estimate that 24.6 of the 38.7 percentage point drop in the vote share of the incumbent parties can not be explained by the incumbency and economic conditions prevailing at that time. Although many studies cited government's tolerance and even involvement in corruption in general, as a major contributing factor in the outcome of the 2002 election, the role played by the 1999 quakes in galvanizing the public anger is mostly overlooked. To our knowledge, only one study, Özel (2003), mentions the earthquake factor, but does not measure it. We hope to show statistically the relevance of this factor.

\section{BACKGROUND, METHOD AND DATA}

No data exists on government's response time to the earthquake disasters, on the number of buildings damaged due to substandard construction, and on when these were constructed. Neither is there any information on how many corrupt officials and contractors are let go because only a few of them were even charged. Consequently, it is not possible to measure the impact of government corruption and ineptitude in regards to the 1999 earthquakes, directly. However, in our opinion, whether voters showed any sensitivity to these can be determined indirectly, through the impact of a variable representing the number of residences and businesses which suffered heavy quake damage in a province per 100 people (henceforth referred to as Q), if one is willing to make some reasonable assumptions. It can be presumed that, the whole country followed the news on government corruption and incompetence, including those related to the earthquakes, and factored these in casting their ballots. The coefficient of a party's previous vote share, in a regression relating the party's 2002 vote share to this variable, Q and other control variables, would capture the blame placed on the party nationwide, for its performance on the earthquake and other fronts. The people living in the provinces affected by the earthquakes in question however would be more sensitive to and better informed about the degree of government corruption and incompetence involved and the parties responsible for these. Furthermore, it will be logical to assume that greater is the number of residences and businesses which suffered heavy damage in a province, in other words, the higher is the $\mathrm{Q}$, the greater is the information each voter in that province is exposed to on the level of corruption involved and on the quality of the relief provided by the government. Under these assumptions, and controlling for other factors, the effect of 
Q on each party's vote share in 2002 election can be viewed as the incremental response of the voters who are better informed and more affected by the government corruption and incompetence. Thus the estimated effect of this variable on a party's vote share can give us some clues as to which parties, if any, were held responsible by the voters and to what extent. The nine provinces which suffered heavy property damage in the 1999 earthquakes are listed in table 1. As can be observed from that table, the intensity of the damage varied considerably between the affected provinces. This and the fact that there are many provinces at hand with zero quake damage, provides us with a good data to measure the effect of $\mathrm{Q}$ on the vote shares of major political parties which participated in the 2002 election. As can be observed in tables 2, 3, and 4, the date political parties came to power, the time they spent in government (at the helm or as a minor partner), and the proportion of municipal administrations they controlled in the earthquake region, exhibit great variation among parties during the decade preceding the 1999 quakes. This will enable us not only to measure but also to interpret the coefficients of $\mathrm{Q}$ in equations relating this variable to the vote shares of the parties.

The Democratic Left Party (DSP), the major incumbent party in 2002, came to power for the first time in June 1997 but got the premiership only seven months before the August 1999 earthquake. The party had only a negligible number of mayors in the quake affected areas, none in the cities which suffered major damage, and none in the provincial centers where the population is concentrated. Thus, any adverse impact of Q on this party's vote share should be considered as the reaction of the voters in the affected areas to government's inefficiency in providing relief and its inability or unwillingness to prosecute corrupt officials and their private sector benefactors, but not to the corruption at the local level, and not to the construction of shoddy buildings.

The second largest incumbent party in 2002, the Nationalist Action Party (MHP), came to power less than three months before the first earthquake in 1999 and after being out of power for two decades. This party controlled almost none of the municipalities in the areas affected by the earthquakes. However, the minister of Public Works and Settlement, which supervises the General Directorate of Disaster Affairs, was from this party. He was accused after the 2002 election by the new government, of cronyism and receiving kickbacks from contracts his ministry granted, in regards to construction of new housing for the earthquake survivors and other relief efforts. Although he was finally found not guilty in 2007 by the Supreme Court, it is not clear if he is vindicated in the public opinion, and of course the verdict was not known at the time of the 2002 election. In fact he was seen as a liability for his party and was forced to resign his post in 2001 by the leader of his party. Eight of his top bureaucrats and forty contractors they have collaborated with have been found guilty in 2008. Therefore any significant negative impact of Q on the Nationalist Action Party's (MHP's) 2002 vote share should be interpreted as a punishment by the quake victims for government incompetence in coming to their aid and for corruption related to the relief efforts, but not for the prequake corruption.

The third incumbent party, the Motherland Party (ANAP), held the premiership of the country in single-party governments between December 1983 and November 1991, 
and in coalition governments, during the March 1996 - June 1996, and June 1997 January 1999 periods. The party was a minor partner in the coalition ruling at the time of the 1999 earthquakes. It controlled substantial number of local administrations in the quake region since 1984. Thus an adverse earthquake effect on this party's vote could be due to the performance of its mayors and/or its cabinet members.

The opposition True Path and Republican People's parties (DYP and CHP), shared power during the 1991-1996 period and both had large number of mayors in the provinces affected by the two earthquakes during the decade preceding the quakes. In making this statement, we are treating the Republican People's Party (CHP) and the Social Democratic Populist Party (SHP) as one party. Initially the latter was in the coalition with the True Path Party (DYP) but after its merger with the former, the coalition continued as DYP-CHP government. If the vote shares of these parties are found to be inversely related to $\mathrm{Q}$, it must be taken as an indication of voters holding parties which controlled central and local administrations during the time the shoddy buildings were built.

If the voters are rational, the Young Party (GP) should either not be affected by the earthquake related events, or benefit from them. This party was formed a few months before the 2002 election by a business tycoon who had no prior political experience.

The Justice and Development Party (AKP) is one of the two parties formed in the second half of 2001 by the members of the Virtue Party (FP) after the dissolution of the latter by the Constitutional Court on grounds that it advocated religion based regime in violation of the constitution. The Virtue Party (FP) itself was formed by the leaders and rank and file of the Welfare Party (RP) which was closed by the Constitutional Court on the same grounds used against the Virtue Party. While Welfare Party (RP) held power only for a year from mid 1996 to mid 1997, many of the mayors in the provinces affected by the 1999 quakes were members of this party since 1994. The Justice and Development Party (AKP) disavowed the anti-Western and pro-Islamist positions of the Virtue and Welfare parties (FP and RP)) and rejected being a continuation of these. The Felicity Party (SP), the other party that emerged from the ashes of the Virtue Party, on the other hand, towed the old party line and received very few votes in 2002. Whether the Justice and Development Party (AKP) is a continuation of the Virtue and Welfare parties (FP and RP) is a contentious issue in Turkey. If this party turns out to have benefited from the government's handling of the earthquake related issues, that would imply that either it was not perceived as a continuation of the Welfare and Virtue parties (RP and FP) or that the mayors of the latter which later joined the Justice and Development Party (AKP) are viewed by the public as not being corrupt. On the other hand, a negative coefficient for Q, for this party, would mean that it is being punished for the sins of the Welfare and Virtue parties (FP and RP) at the local level.

The Motherland party (ANAP) served in the central government longer than the True Path Party (DYP), and the True Path Party (DYP) longer than the Republican People's Party / Social Democratic Populist Party (CHP/SHP). As can be seen from Table 4 however, the Republican People's Party / Social Democratic Populist Party 
(CHP/SHP) had more mayors in the population centers which suffered major earthquake damage, than the other two parties mentioned, during 1989-1994, and about the same number as them during 1994-1999. The True Path Party (DYP) appears to have controlled slightly more mayors in these cities in both periods in question, than the Motherland Party (ANAP). Thus the differences in the estimated coefficients of the Q variable in various party equations will allow us to determine whether the electorate blamed the parties which controlled more of the city administrations, more. For example if the Republican People's Party (CHP) is found to be affected more than the other two parties, despite serving a shorter time in central government, it can be attributed to its performance at the local level.

To measure the impact of $\mathrm{Q}$ on vote shares of various parties, we estimated vote equations for each of the major political parties which participated in the 2002 parliamentary election. These equations included other independent variables as well, to control for the effects of other factors. We fitted these equations to cross-provincial data, utilizing the Seemingly Unrelated Regressions procedure of Zellner (1962). This procedure estimates the parameters more efficiently by taking into account the correlations between the residuals of different vote equations. We dropped from our sample, provinces in which the Kurdish-nationalist Democratic People's Party (DEHAP) has received more than 10 percent of the vote in 2002. This eliminated 17 of the 81 provinces, all from eastern and south eastern sections of the country. These are listed in the notes of Table 5. The behavior of voters in these provinces is considerably different than in the rest of the country. It is largely ethnic based and is affected a lot by the terror activities in this region and the government's response to them. Akarca (2008) contrasts the voting patterns in this region with the pattern in the remaining 64 provinces. It should be noted that only 9.1 percent of the registered voters in 2002 resided in the provinces excluded. The 2002 vote shares of the political parties considered sum to 88.2 percent of the votes cast in the provinces included in our sample and 85.2 percent of the votes cast nationwide. Thus there was no need to restrict the sum of dependent variables to 100 percent.

One of the important factors that needed to be controlled for, in measuring the impact of Q, was the unprecedented amount of inter-party vote shifts that had occurred across the country between 1999 and 2002. During that period, the three incumbent parties, the Democratic Left Party (DSP), the Nationalist Action Party (MHP) and the Motherland Party (ANAP), experienced a 38.7 percentage point drop in their aggregate vote share. In addition, the opposition True Path Party (DYP) lost 2.5 percentage points of its vote share. Furthermore, after the closing of the main opposition Virtue Party (FP), 15.4 percent of the electorate which voted for it in 1999 had to choose another party in 2002. In short, more than half of the voters switched parties between the 1999 and 2002 elections. Consequently in each party's vote equation, the 1999 vote shares of other parties were included beside its own. Akarca (2008), who studied the vote movements between the 1999 and 2002 elections in detail, showed that the vote shifts which occurred were essentially from the Virtue, Nationalist Action, Motherland and True Path parties (FP, MHP, ANAP and DYP) to the Justice and Development Party (AKP), from the Democratic Left Party (DSP) to the Republican People's and Young parties (CHP and 
GP), and from the Democratic Left, Nationalist Action and Motherland parties (DSP, MHP and ANAP) to the True Path Party (DYP). Thus the 1999 vote shares included in the Democratic Left Party (DSP), Nationalist Action Party (MHP) and Motherland Party (ANAP) were their own only, and in the Young Party (GP) equation that of the Democratic Party (DSP) only. The Justice and Development Party (AKP) equation on the other hand included the 1999 vote shares of the Virtue Party (FP), Nationalist Action Party (MHP), Motherland Party (ANAP), and the True Path Party (DYP). The True Path Party (DYP) equation included, besides its own, the 1999 vote shares of the Democratic Left Party (DSP), Nationalist Action Party (MHP), and the Motherland Party (ANAP) as well. The Republican People's Party (CHP) equation included, besides its own lagged vote share, the vote share of the Democratic Left Party (DSP) in the previous election.

As shown in Akarca (2008) and Akarca and Tansel (2007), the vote shares of parties in a province depend also on the socioeconomic characteristics of the population living in that province. For that reason, we included in each vote equation, mean years of schooling for population over age of 6 , the urbanization rate, and the proportion of women in non-agricultural employment as well, as independent variables.

Finally, dummy variables are considered for the following provinces, as is done in Akarca (2008): Bayburt, Kilis, Malatya, Osmaniye, Rize, Sakarya, Bartın, and Yalova. In the first two of these, independent candidates received considerable amount of votes. In the first one, in addition, the Felicity Party (SP) made an unusually strong showing, receiving a vote share which was almost five times its national share of 2.5 percent. In the third one, the votes which went to an independent candidate in 1999 returned to one of the political parties. Osmaniye, Rize and Sakarya are the home provinces of the leaders of the Nationalist Action Party (MHP), the Motherland Party (ANAP) and the Young Party (GP), respectively. Their favorite son candidacies in these provinces brought to their parties extra votes. Other party leaders did not have a strong identification with any particular province. The dummy variables for Bartin and Yalova are included because these observations constitute outliers. Even though the Nationalist Action party lost votes between 1999 and 2002 in every other province, its vote share in Bartın and Yalova increased. Although substantial amount votes went to an independent candidate in Elazığ and to a minor regional party in Sivas, no dummy variables were considered for these provinces because that was the case in 1999 as well. The equations are first estimated including all of the dummy variables. Then they are re-estimated after dropping from each equation the dummy variables with parameters exhibiting less than 5 percent significance (in a one-tail test) unless their absolute values were larger than 5 . For brevity only the final regressions are presented.

\section{EMPIRICAL RESULTS}

Regressions relating 2002 vote shares of major political parties to the variables mentioned in the previous section are presented in table 5. We will comment here only on the results pertaining to the 1999 earthquakes. Other inferences that can be drawn are discussed in Akarca (2008) and are outside the scope of the present paper. 
In Table 5, the 2002 vote shares of the Justice and Development Party (AKP), the Republican People's Party (CHP), the Young Party (GP), the Democratic Left Party (DSP), the Nationalist Action Party (MHP), the Motherland Party (ANAP), and the True Path Party (DYP) are represented by the symbols: AKP02, CHP02, GP02, DSP02, MHP02, ANAP02 and DYP02, respectively. The 1999 vote shares of the Virtue Party (FP), the Republican People's Party (CHP), the Democratic Left Party (DSP), the Nationalist Action Party (MHP), the Motherland Party (ANAP) and the True Path Party (DYP) are represented by the symbols: FP99, CHP99, DSP99, MHP99, ANAP99 and DYP99, respectively. The symbols $\mathrm{S}, \mathrm{U}$, and $\mathrm{W}$ are used to represent the mean years of schooling, the urbanization rate, and the proportion of women in non-agricultural employment, respectively. Q stands for the number of residences and businesses which suffered heavy damage in the 1999 earthquakes, per hundred people. Province names are used to represent the dummy variables, which take the value of one for the named province and zero for all others.

The estimated coefficients reported in the table show that there was a general shift in votes, from the extreme right Nationalist Action Party (MHP) and the center right Motherland and True Path parties (ANAP and DYP) towards the Justice and Development Party (AKP). This was even more pronounced in provinces which suffered heavy earthquake damage. In the latter provinces votes shifted towards the Justice and Development Party (AKP) also from the center left Republican People's and Democratic Left parties (CHP and DSP). It appears that the Justice and Development Party (AKP) was either not seen by voters as the continuation of the Welfare and Virtue parties (RP and FP), or that the mayors of the latter were not seen as corrupt. All three of the incumbent parties suffered vote losses in the quake zone that varied with the level of per capita damage encountered. The Nationalist Action Party (MHP) paid the highest price. The Democratic Left Party (DSP), the party of the prime minister, was affected also but only slightly. It appears that voters held the party in charge of the ministry responsible for earthquake relief especially accountable for the incompetence and corruption exhibited after the earthquakes. The fact that the Motherland Party (ANAP) was affected more than the Democratic Left Party (DSP), despite being a minor partner in the ruling coalition, indicates that voters blamed the parties which participated in the central and local administrations in the past as well. This conclusion is reinforced by the fact that the adverse impacts of the variable Q on the opposition Republican People's and the True Path parties (CHP and DYP) were much larger than that on the incumbent Democratic Left and Motherland parties (DSP and ANAP). The fact that the adverse impact on the Republican People's Party (CHP) was 63 percent higher than that on the True Path Party (DYP) which served in the previous central governments longer, shows that control of city administrations mattered as well. As we had mentioned above, the mayors serving in the quake-effected area who were affiliated with the former party were more than those affiliated with the latter. This was true even more so in the heavily populated provincial centers. Because there are no parties which controlled local governments but not served in central government, we are unable to assess relative blame placed by voters on the central and local governments. A survey conducted by Adaman and Çarkoğlu (2001) however show that, in general, urban dwellers in Turkey, perceive central and local 
governments to be both corrupt but the central government to be more corrupt. Our results here do not contradict that.

For the three incumbent parties, the Democratic Left Party (DSP), the Nationalist Action Party (MHP) and the Motherland Party (ANAP), the estimated coefficients of their own lagged vote variables imply that in a typical province they have lost almost all, two-thirds, and four-fifths, of their 1999 votes, respectively, controlling for other factors. These are far more than the usual amounts of erosion that can be expected in the vote shares of incumbent parties due controversial decisions they make while in office and due to voter efforts to create checks and balances against their power. The depreciation in the political capitals of the ruling parties implied by these figures is substantially higher than what Akarca and Tansel (2007) found for the period 1991-1995, for example. These losses no doubt reflect partially the disappointment of their supporters all over the country with the way they have responded to the earthquakes and with their failure to stop or prosecute the people involved in earthquake related corruption. These parties were tainted by some non-earthquake related corruption as well. In fact, some of their leaders and cabinet members were prosecuted later for personal involvement in a variety of corruption cases. The prime minister's old age, his refusal to relinquish his power even temporarily despite his severe illness, and his self-publicized rift with the president which shattered public confidence in his government also contributed to the vote loss of incumbent parties. The coefficients of the $\mathrm{Q}$ variable should be interpreted as an addition to these in the provinces affected by the earthquakes directly.

An analysis of the coefficients of the dummy variables reveal that votes gained by the Justice and Development Party (AKP) in Sakarya, due to quake related events, were largely offset by the votes it lost to Young Party (GP), the leader of which ran in the province as a favorite son. In Yalova, vote shares of the Nationalist Action Party (MHP) and the Republican People's Party (CHP) were unusually high and that of the Justice and Development Party (AKP) unusually low, due to special local circumstances. The Justice and Development Party's (AKP's) gain and the Republican People's Party's (CHP's) loss in this province due to quake related events were almost exactly offset by other factors working in the opposite direction. In the case of the Nationalist Action Party (MHP), the impact of other factors working in favor of the party in Yalova was about twice as much as the adverse effects of the quake related factors.

\section{CONCLUSIONS}

Our findings suggest that, in casting their ballots in 2002, the Turkish voters have taken into account the performance of all governments that contributed to the magnification of the earthquake disasters. Not just the incumbent parties at the time of the earthquakes but others which were in power when the substandard buildings were built were also held accountable. Each and every party which ruled during the 1983 1999 period was adversely affected by the earthquake damage. The votes lost by these parties went to the Justice and Development Party (AKP). The Turkish voters appear to have allocated the blame rationally, taking into consideration the division of labor in the 
central government, and the relative influence the parties had on local administrations. When they are made aware of public corruption, Turkish voters seem to be willing to use their electoral powers to vote out the politicians who participated in it or allowed it to happen. New earthquake related laws and regulations enacted, disaster relief agencies reorganized, and the cabinet members and high level bureaucrats tried for corruption, after the 2002 election, show that the Turkish politicians realize this and are responding accordingly. This implies that corruption does not have to be a persistent problem in Turkey and can be reduced through increased transparency and democracy.

\section{REFERENCES}

Adaman, F. and Çarkoğlu, A. (2001). Perceptions of central and local governments' engagement in corruptive activities: The case of Turkey. Economic Research Forum (ERF) Working Paper, No. 0103.

Akarca, A. (2008). Inter-party vote movements in Turkey between 1999 and 2002: A statistical analysis using cross-provincial election data. Unpublished manuscript.

Akarca, A. T. and Tansel, A. (2007). Social and economic determinants of Turkish voter choice in the 1995 parliamentary election. Electoral Studies 26, 633-647.

Akarca, A. T. and Tansel, A. (2006). Economic performance and political outcomes: An analysis of the Turkish parliamentary and local election results between 1950 and 2004 . Public Choice 129, 77-105.

Alesina, A and Weder, B. (2002). Do corrupt governments receive less foreign aid? American Economic Review 92, 1126-1137.

Escalares, M., Anbarci, N. and Register C. A. (2007). Public sector corruption and major earthquakes: A potential deadly interaction. Public Choice 132, 209-230.

Green, P. (2005). Disaster by design: Corruption, construction and catastrophe. British Journal of Criminology 45, 528-546.

Habib, M. and Zurawicki, L. (2002). Corruption and direct foreign investment. Journal of International Business Studies 33, 291-307.

Mauro, P. (1997). The effects of corruption on growth, investment and government expenditure: A cross-country analysis. In Corruption and global economy ed., K. A. Elliot, Washington, D.C: Institute for International Economics.

Mauro, P. (1995). Corruption and growth. Quarterly Journal of Economics 110, 681-712. 
Meon, P. and Sekkat, K. (2005). Does corruption grease or sand the wheels of growth. Public Choice 122, 69-97.

Mishra, A. (2005). Persistence of corruption: Some theoretical perspectives. World Development 34, 349-358.

Mo, P. (2001). Corruption and economic growth. Journal of Comparative Economics 29, 66-79.

Murphy, K., Shleifer, A. and Vishny, R. (1993). Why is rent-seeking so costly to growth? American Economic Review 83, 409-414.

Murphy, K., Shleifer, A. and Vishny, R. (1991). The allocation of talent: Implications for growth. Quarterly Journal of Economics 106, 503-530.

Özel, S. (2003). Turkey at the polls: After the tsunami. Journal of Democracy 14, 80-94.

Pellegrini, L. and Gerlagh, R. (2004). Corruption effects on growth and its transmission channels. Kyklos 57, 429-456.

Tanzi, V. and Davoodi, H. (1997). Corruption, public investment and growth. IMF Working Paper No. 97/139.

Zellner, A. (1962). An efficient method of estimating seemingly unrelated regressions and tests for aggregation bias. Journal of the American Statistical Association 57, 348368 
Table 1

Number of residences and businesses which suffered heavy damage in the 1999 earthquakes ${ }^{a}$

\begin{tabular}{|l|c|c|}
\hline PROVINCES & QUANTITY & $\begin{array}{c}\text { QUANTITY PER } \\
\text { 100 PEOPLE }\end{array}$ \\
\hline Bolu & 2750 & 1.0161 \\
\hline Bursa & 128 & 0.0060 \\
\hline Düzce & 15134 & 4.8157 \\
\hline Eskişehir & 111 & 0.0157 \\
\hline İstanbul & 3306 & 0.0330 \\
\hline Kocaeli & 41041 & 3.4028 \\
\hline Sakarya & 29701 & 3.9278 \\
\hline Yalova & 14473 & 8.5846 \\
\hline Zonguldak & 114 & 0.0185 \\
\hline
\end{tabular}

Table 1 notes:

a/ In 1999 the administrative division of the country was slightly different. The table is based on the structure prevailing in 2002.

Source:

Figures on the first column are provided by the General Directorate of Disaster Affairs (Ministry of Public Works and Settlement, the Republic of Turkey) and reflects the most recent revision dated 22 April 2003. The second column is obtained by dividing the figures in the first column by the province's 2000 population given by the State Institute of Statistics (Prime Ministry, the Republic of Turkey). 


\section{Table 2}

Political parties ruling between 1983 and 2002

\begin{tabular}{|c|c|c|c|}
\hline POLITICAL PARTIES ${ }^{\text {a }}$ & PERIODS & $\begin{array}{c}\text { PRIME } \\
\text { MINISTER }\end{array}$ & $\begin{array}{l}\text { COALITION } \\
\text { GOV. }\end{array}$ \\
\hline Motherland Party (ANAP) & $\begin{array}{l}\text { Dec. } 1983 \text { - Nov. } 1991 \\
\text { Mar. } 1996 \text { - June } 1996 \\
\text { June } 1997 \text { - Jan. } 1999 \\
\text { May } 1999 \text { - Nov. } 2002\end{array}$ & $\begin{array}{l}\text { YES } \\
\text { YES } \\
\text { YES } \\
\text { NO }\end{array}$ & $\begin{array}{l}\text { NO } \\
\text { YES } \\
\text { YES } \\
\text { YES }\end{array}$ \\
\hline True Path Party (DYP) & $\begin{array}{l}\text { Nov. } 1991 \text { - Mar. } 1996 \\
\text { Mar. } 1996 \text { - June } 1997\end{array}$ & $\begin{array}{l}\text { YES } \\
\text { NO }\end{array}$ & $\begin{array}{l}\text { YES } \\
\text { YES }\end{array}$ \\
\hline $\begin{array}{l}\text { Republican People's Party (CHP) / } \\
\text { Social Democratic Populist Party (SHP) b }\end{array}$ & Nov. 1991 - Mar. 1996 & NO & YES \\
\hline Welfare Party (RP) & June 1996 - June 1997 & YES & YES \\
\hline Democratic Left Party (DSP) & $\begin{array}{l}\text { June } 1997 \text { - Jan. } 1999 \\
\text { Jan. } 1999 \text { - Nov. } 2002\end{array}$ & $\begin{array}{l}\text { NO } \\
\text { YES }\end{array}$ & $\begin{array}{l}\text { YES } \\
\text { YES }\end{array}$ \\
\hline Nationalist Action Party (MHP) & May 1999 - Nov. 2002 & NO & YES \\
\hline
\end{tabular}

Table 2 notes:

a/ In paranthesis are the Turkish acronyms of political parties.

b/ Between November 1991 and February 1995 the Social Democratic Populist Party (SHP) was in power. This party joined the Republican People's Party (CHP) in February 1995. The coalition government continued until March 1996 with the latter party as the official partner.

Source:

Turkish Grand National Assembly web site:

(www.tbmm.gov.tr/kutuphane/hukumetler.html). 
Table 3

Party affiliations of mayors of provincial and district centers where some residences suffered heavy damage in the 1999 earthquakes ${ }^{\text {a }}$

\begin{tabular}{|l|c|c|c|c|}
\hline \multirow{2}{*}{ POLITICAL PARTIES } & \multicolumn{2}{|c|}{$1989-1994$} & \multicolumn{2}{c|}{ 1994-1999 } \\
\cline { 2 - 5 } & $\begin{array}{c}\text { Provincial } \\
\text { Centers }\end{array}$ & $\begin{array}{c}\text { District } \\
\text { Centers }\end{array}$ & $\begin{array}{c}\text { Provincial } \\
\text { Centers }\end{array}$ & $\begin{array}{c}\text { District } \\
\text { Centers }\end{array}$ \\
\hline Motherland Party (ANAP) & 0 & 21 & 2 & 41 \\
\hline True Path Party (DYP) & 2 & 24 & 2 & 18 \\
\hline Republican People's Party (CHP) / \\
Social Democratic Populist Party (SHP) & 7 & 50 & 1 & 18 \\
\hline Welfare Party (RP) & 0 & 1 & 4 & 27 \\
\hline Democratic Left Party (DSP) & 0 & 96 & 9 & 109 \\
\hline Nationalist Action Party (MHP) & 0 & 0 & 0 & 3 \\
\hline
\end{tabular}


Table 3 notes:

a/ The provinces in question are the following: Bolu, Bursa, Düzce, Eskişehir, İstanbul, Kocaeli, Sakarya, Zonguldak and Yalova. Between 1989 and 2002 the administrative division of the country has changed. The table is based on the structure prevailing in 2002. Party affiliations of some mayors changed between two elections. The table reflects the distributions immediately after the elections in 1984 and 1989.

b/ In paranthesis are the Turkish acronyms of political parties.

c/ The Republican People's Party was closed between 1983 and 1993. This party and the Social Democratic Party entered the 1994 local elections seperately but merged in 1995.

\section{Source:}

Compiled by authors, using the data provided by the State Institute of Statistics (Prime Ministry, the Republic of Turkey) on the results of the 1984 and 1989 elections, and by the General Directorate of Disaster Affairs (Ministry of Public Works and Settlement, the Republic of Turkey) on the property damage caused by the 1999 earthquakes. 


\section{Table 4}

\section{Party affiliations of mayors of provincial and district centers where more than $10 \%$ of residences suffered heavy damage in the 1999 earthquakes ${ }^{a}$}

\begin{tabular}{|c|c|c|c|c|}
\hline \multirow{2}{*}{ POLITICAL PARTIES } & \multicolumn{2}{|c|}{ 1989-1994 } & \multicolumn{2}{|c|}{ 1994-1999 } \\
\hline & $\begin{array}{l}\text { Provincial } \\
\text { Centers }\end{array}$ & $\begin{array}{l}\text { District } \\
\text { Centers }\end{array}$ & $\begin{array}{l}\text { Provincial } \\
\text { Centers }\end{array}$ & $\begin{array}{l}\text { District } \\
\text { Centers }\end{array}$ \\
\hline Motherland Party (ANAP) & 0 & 2 & 0 & 2 \\
\hline True Path Party (DYP) & 1 & 4 & 1 & 3 \\
\hline $\begin{array}{l}\text { Republican People's Party (CHP) / } \\
\text { Social Democratic Populist Party (SHP) }\end{array}$ & 4 & 6 & 1 & 1 \\
\hline Welfare Party (RP) & 0 & 1 & 3 & 7 \\
\hline Democratic Left Party (DSP) & 0 & 0 & 0 & 0 \\
\hline Nationalist Action Party (MHP) & 0 & 0 & 0 & 0 \\
\hline TOTAL & 5 & 13 & 5 & 13 \\
\hline
\end{tabular}


Table 4 notes:

a/ The provinces in question are the following: Bolu, Düzce, Kocaeli, Sakarya, and Yalova. Centers with more than 10 percent heavy damage are the following: Bolu, Düzce, Gölyaka, Kaynaşlı, İzmit, Gölcük, Karamürsel, Körfez, Adapazarı, Akyazı, Yalova, Altınova, and Çiftlikköy. Between 1999 and 2002 the administrative division of the country has changed. The table is based on the structure prevailing in 2002. Party affiliations of some mayors changed between two elections. The table reflects the distributions immediately after the elections in 1984 and 1989.

b/ In paranthesis are the Turkish acronyms of political parties.

c/ The Republican People's Party was closed between 1983 and 1993. This party and the Social Democratic Party entered the 1994 local elections seperately but merged in 1995.

Source:

Compiled by authors, using the data provided by the State Institute of Statistics (Prime Ministry, the Republic of Turkey) on the results of the 1984 and 1989 elections, and by the General Directorate of Disaster Affairs (Ministry of Public Works and Settlement, the Republic of Turkey) on the property damage caused by the 1999 earthquakes. 
Table 5

Regressions estimated

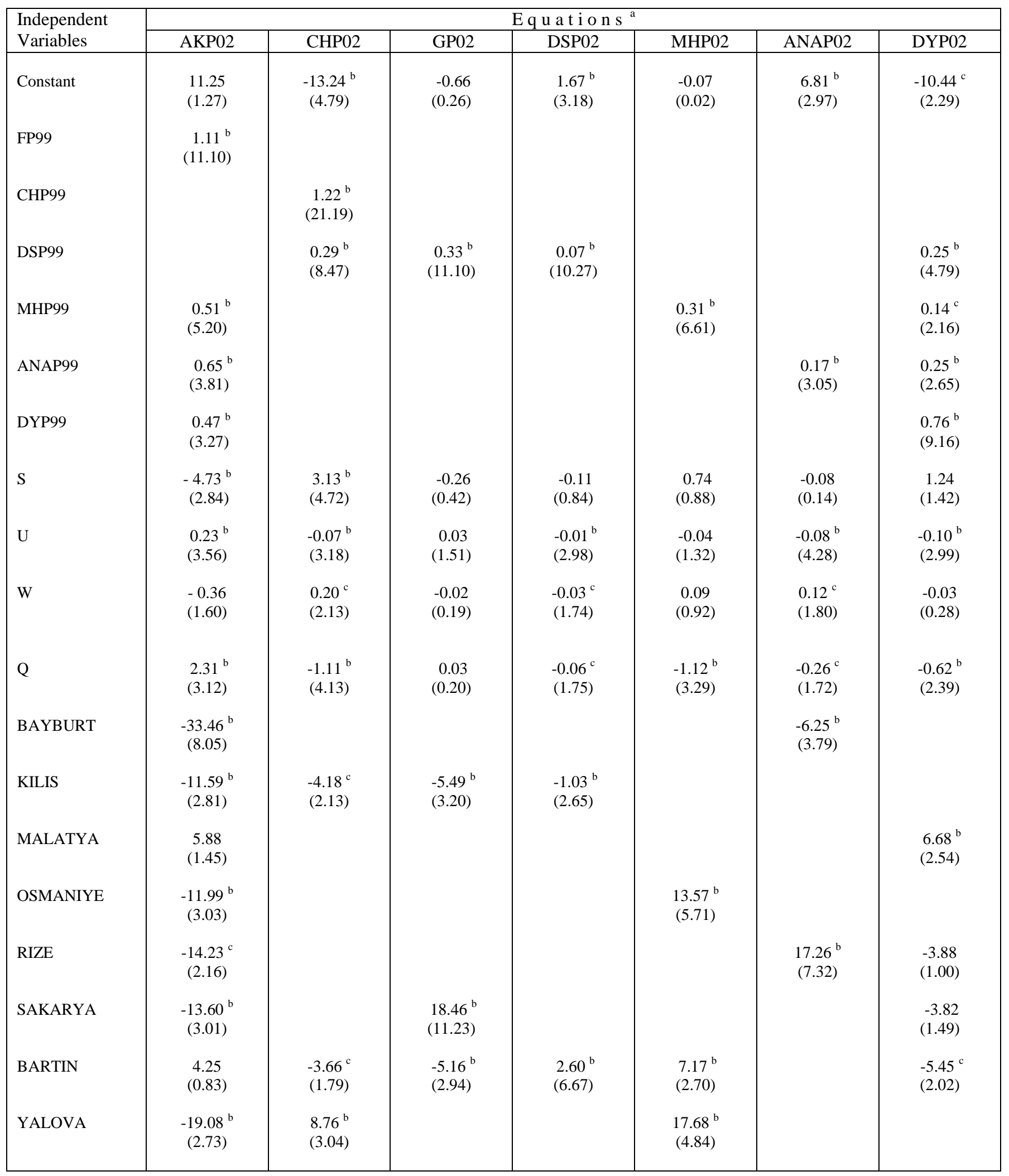


Table 5 notes:

a/ For the definitions of variables, see Section 3. The sample includes 64 provinces, excluding the following 17 provinces: Adıyaman, Ağrı, Bingöl, Bitlis, Diyarbakır, Hakkari, Kars, Mardin, Muş, Siirt, Tunceli, Şanlıurfa, Van, Batman, Şırnak, Ardahan and Iğdır. Only 9.1 percent of the registered voters resided in the latter provinces in 2002. In 1999 the administrative division of the country was slightly different. The structure prevailing in 2002 is used. The equations are estimated as a system of "seemingly unrelated regressions," using the procedure of Zellner (1962). The system weighted Rsquare is 0.89 . The numbers in parantheses are the t-values in absolute value.

b/ Significant at 1 percent level (one-tail test) .

c/ Significant at 5 percent level (one-tail test).

\section{Source:}

Regressions are computed by the authors. The vote shares of political parties are computed using the data provided by the State Institute of Statistics (Prime Ministry, the Republic of Turkey) on the results of the 1999 and 2002 elections. S, U, and W variables are computed utilizing the 2000 Census data provided by the State Institute of Statistics (Prime Ministry, the Republic of Turkey). In computing mean years of schooling (S) for each province, $15,11,8$, and 5 years of schooling are attributed respectively, to university, high school, middle school, and primary school graduates in the province. Two years worth of schooling is assumed for those who are literate but not a graduate of any school. The $\mathrm{Q}$ variable is constructed, using the earthquake damage data provided by the General Directorate of Disaster Affairs (Ministry of Public Works and Settlement, the Republic of Turkey) and the 2000 census population figures reported by the State Institute of Statistics (Prime Ministry, the Republic of Turkey). 